\title{
9: 5221419-5223967
}

National Cancer Institute

\section{Source}

National Cancer Institute. 9:5221419-5223967. NCI Thesaurus. Code C45149.

Physical location of INSL4_Gene 